\title{
PENINGKATAN PRESTASI BELAJAR IPA FISIKA DENGAN MENGGUNAKAN PENDEKATAN PROBLEM POSSING ENGAN LATAR PEMBELAJARAN KOOPERATIF KELAS XI-ADM.A SMK NEGERI 1 NARMADA KABUPATEN LOMBOK BARAT TAHUN PELAJARAN 2017-2018
}

\author{
H. M. Yusuf AS ${ }^{1)}$, Munawir'1), Lalu Syaifulbakhry1) \\ 1)SMKN 1 Narmada, Kabupaten Lombok Barat, NTB, Indonesia \\ Corresponding author: H. M. Yusuf AS \\ E-mail : hajiyusuf64@gmail.com
}

Diterima 04 Oktober 2021, Direvisi 20 Oktober 2021, Disetujui 20 Oktober 2021

\begin{abstract}
ABSTRAK
Belajar merupakan suatu kegiatan kreatif. Belajar bukan berarti hanya menyerap tetapi juga mengkonstruk pengetahuan. Belajar IPA Fisika akan optimal jika siswa terlibat secara aktif dalam membuat, bukan hanya strategi penyelesaian, tetapi juga masalah yang membutuhkan strategi tersebut.Menurut Upu ( 2003:10) Problem Possing dapat dilakukan secara individu atau kalsikal ( classical), berpasangan ( in pairs ), atau secara berkelompok( groups ). Masalah atau soal yang diajukan oleh siswa secara individu tidak memuat intervensi dari siswa ini. hal ini dapat mengakibatkan soal kurang berkembang atau kandungan informasinya kurang lengkap. Soal yang diajukan secara berpasangan dapat lebih berbobot dibanding soal yang diajukan secara individu, dengan syarat terjadi kolaborasi di antara kedua siswa yang berpasangan tersebut. Jika soal dirumuskan oleh suatu kelompok kecil ( tim ), maka kualitasnya akan lebih baik dari aspek tingkat keterselesaian maupun kandungan informasinya. Kerjasama diantara siswa dapat memacu kreativitas serta saling melengkapi kekurangan mereka.Pada pembelajaran kooperatif, siswa dibagi kedalam kelompok-kelompok kecil yang heterogen. Mereka akan bekerja sebagai sebuah tim untuk memahami materi pelajaran dan meyelesaikan tugas yang diberikan. Oleh karena itu penulis perlu melakukan penelitian tindakan kelas dengan judul Peningkatkan Prestasi Belajar IPA Fisika dengan Menggunakan Pendekatan Problem Possing dengan Latar Pembelajaran Kooperatif Kelas XI-ADM.A SMK Negeri 1 NarmadaTahun Pelajaran 2017-2018.
\end{abstract}

Kata Kunci: problem possing; cooperative learning; prestasi belajar.

\begin{abstract}
Learning is a creative activity. Learning does not mean only absorbing but also constructing knowledge. Learning Science Physics will be optimal if students are actively involved in making, not only solving strategies, but also problems that require these strategies. According to Upu (2003:10) Problem Possing can be done individually or classically (classical), in pairs (in pairs), or in groups (groups). Problems or questions posed by students individually do not contain intervention from these students. this can result in less developed questions or incomplete information content. Questions posed in pairs can be more weighty than questions posed individually, provided that there is collaboration between the two students in pairs. If the questions are formulated by a small group (team), then the quality will be better in terms of the level of completion and information content. Cooperation among students can stimulate creativity and complement each other's shortcomings. In cooperative learning, students are divided into small, heterogeneous groups. They will work as a team to understand the subject matter and complete the assigned tasks. Therefore, the authors need to conduct classroom action research with the title Improving Physics Science Learning Achievement by Using a Problem Possing Approach with a Cooperative Learning Background for Class XI-ADM.A SMK Negeri 1 Narmada for the 2017-2018 academic year.
\end{abstract}

Keywords: problem possing; cooperative learning; learning achievement.

\section{PENDAHULUAN}

Sikap kritis dan rasa ingin tahu (curiosity) merupakan sifat alamiah yang dimiliki manusia. sifat ini sangat bermanfaat sebagai motivator bagi seseorang untuk terus menambah pengetahuan yang dimilikinya. Akan tetapi sering kali orang dewasa tidak mengacukan pertanyaan anak, bahkan menganggap anak lancang sehingga membuat anak takut bertanya. Hal ini juga terjadi di sekolah. Akibatnya dalam mengikuti pembelajaran, anak enggan atau malas bertanya, meskipun belum 
mengerti materi yang diberikan. Rasa ingin tahu siswa semakin menurun dan berdampak pada rendahnya motivasi belajar.

Agar siswa termotivasi untuk belajar secara mandiri dan sepanjang hayat, maka rasa ingin tahu siswa perlu dibangkitkan dan dikembangkan. Pendekatan Problem Possing dalam pembelajaran dapat melatih siswa untuk mengajukan pertanyaan-pertanyaan atau soalsoal yang berkaitan dengan materi yang dipelajari. Pada pembelajaran yang menerapkan Problem Possing, siswa hanya diminta menyelesaikan soal yang disediakan.Siswa dituntun untuk mengajukan masalah atau pertanyaan sesuai minat mereka dan memikirkan cara penyelesaiannya. Perhatian dan komunikasi IPA Fisika siswa melalui pendekatan Problem Possing akan lebih baik, karena pertanyaan atau soal yang berkualitas oleh siswa yang mempunyai perhatian sungguh-sungguh terhadap pelajaran IPA Fisika.

Menurut Upu (2003:10) Problem Possing dapat dilakukan secara individu atau kalsikal (classical), berpasangan ( in pairs), atau secara berkelompok (groups). Masalah atau soal yang diajukan oleh siswa secara individu tidak memuat intervensi dari siswa ini. hal ini dapat mengakibatkan soal kurang berkembang atau kandungan informasinya kurang lengkap. Soal yang diajukan secara berpasangan dapat lebih berbobot dibanding soal yang diajukan secara individu, dengan syarat terjadi kolaborasi di antara kedua siswa yang berpasangan tersebut. Jika soal dirumuskan oleh suatu kelompok kecil ( tim ), maka kualitasnya akan lebih baik dari aspek tingkat keterselesaian maupun kandungan informasinya. Kerjasama diantara siswa dapat memacu kreativitas serta saling melengkapi kekurangan mereka. Selain itu, hasil wawancara Efendi ( 2000:57 ) terhadap siswa kelas XI ADM.A SMK Negeri 1 Narmada menunjukkan bahwa ketika siswa mengalami kesulitan dalam menyelesaikan tugas pengajuan soal berdasarkan masalah, mereka akan bekerja sama dengan temannya. Oleh karena itu, penulis memilih pembelajaran kooperatif sebagai latar pendekatan Problem Possing dalam mengajarkan materi pembelajaran IPA Fisika pada siswakelas XI ADM.A semester Ganjil. Pada pembelajaran kooperatif, siswa dibagi kedalam kelompokkelompok kecil yang heterogen. Mereka akan bekerja sebagai sebuah tim untuk memahami materi pelajaran dan meyelesaikan tugas yang diberikan

\section{METODE PENELITIAN Subjek Penelitian}

Penelitian ini merupakan penelitian tindakan kelas, yang dilakukan secara bertahap-tahap sampai mendapatkan hasil yang diinginkan. Jumlah siswa kelas XI ADM.A secara keseluruhan sebanyak 30 orang.

\section{Setting Penelitian}

1. PTK dilakukan di SMK Negeri 1 Narmada Kabupaten Lombok BaratTahun Pelajaran 2017-2018 .

2. Kelas XI- di SMK Negeri 1 Narmada terdiri dari 6 kelas dan jumlah siswa pada masingmasing kelas relatif besar dibadingkan dengan SMK lainnya yang ada di wilayah Kabupaten Lombok Barat.

3. PTK dilakukan pada siswa kelas XI ADM.A dengan jumlah 30 orang

\section{Rancangan Penelitian}

1. Tindakan dilaksanakan dalam 3 siklus.

2. Kegiatan dilaksanakandalam semester ganjiltahun pelajaran 2017-2018 .

3. Lama penelitian 6 pekan efektif dilaksanakan mulai tanggal 06 September 2017 sampai dengan 11 Oktober 2017.

\section{Variabel Penelitian}

Dalam penelitian tindakan kelas ini variabel yang diteliti adalah peningkatan prestasi belajarIPA Fisika pada siswa kelas XI ADM.A diSMK Negeri 1 Narmada Tahun Pelajaran 2017-2018

Variabel tersebut dapat dituliskan kembali sebagai berikut :

\begin{tabular}{|c|c|c|}
\hline \multirow{6}{*}{\multicolumn{2}{|c|}{$\begin{array}{l}\text { Variabel } \\
\text { Harapan } \\
\text { Variabel } \\
\text { Tindakan }\end{array}$}} & $\begin{array}{l}\text { Peningkatan Prestasi } \\
\text { BelajarlPA }\end{array}$ \\
\hline & & FisikaKelas \\
\hline & & ADM.A SMK Negeri 1 \\
\hline & & Narmada \\
\hline & & $\begin{array}{l}\text { Penerapan } \\
\text { pendekatan } \\
\text { pembelajaran }\end{array}$ \\
\hline & & $\begin{array}{lr}\text { Problem } & \text { Possing } \\
\text { dengan } & \text { latar } \\
\text { pembelajaran } & \\
\text { kooperatif } & \end{array}$ \\
\hline
\end{tabular}

Adapun indikator yang diteliti dalam variabel harapan terdiri dari :

1. Kemampuan Siswa dalam pembelajaran IPA Fisika

2. Kemampuan siswa dan guru menguasai materi IPA Fisika melalui penerapan pendekatan pembelajaran Problem Possing dengan latar pembelajaran kooperatif

3. Keefektifan pendekatan pembelajaran Problem Possing dengan latar pembelajaran kooperatif dalam pembelajaran IPA Fisika. 
Sedangkan variabel tindakan memiliki indikator sebagai berikut :

1. Tingkat kualitas perencanaan

2. Kualitas perangkat observasi

3. Kualitas operasional tindakan

4. Kesesuaian perencanaan dengan tindakan kelas

5. Kesesuaian teknik yang digunakan dalam meningkatkan prestasi belajar siswa

6. Tingkat efektifitas pelaksanaan penerapan pendekatan pembelajaran Problem Possing dengan latar pembelajaran kooperatif

7. Kemampuan siswa dan gurumenerapkan pendekatan pembelajaran Problem Possing dengan latar pembelajaran kooperatif

\section{Teknik Analisis Data}

Dalam analisis data teknik yang digunakan adalah ;

\section{Kuantitatif}

Analisis ini digunakan untuk menghitung besarnya peningkatan prestasi siswa dalam pembelajaran IPA Fisika melalui penerapan pendekatan pembelajaran Problem Possing dengan latar pembelajaran kooperatif dengan menggunakan prosentase ( \% ).

\section{Kualitatif}

Teknik analisis inidigunakan untuk memberikan gambaran hasil penelitian secara ; reduksi data, sajian deskriptif, dan penarikan simpulan.

\section{HASIL DAN PEMBAHASAN}

\section{Analisis Hasil Kegiatan}

Setelah dilakukan tindakan pada siklus 1 , siklus 2 dan siklus 3 menunjukkanhasil sebagai berikut.

Tabel 1. Analisis Hasil Tes Pelajaran IPA Fisika dalam Meningkatkan Prestasi belajar siswa dengan menerapkan pembelajaran Problem Possing

\begin{tabular}{lccc}
\cline { 2 - 4 } & $\begin{array}{c}\text { Skor } \\
\text { sebelum }\end{array}$ & $\begin{array}{c}\text { Skor } \\
\text { setelah }\end{array}$ & $\begin{array}{c}\text { Skor } \\
\text { setelah }\end{array}$ \\
\cline { 2 - 4 } & Tindakan & Tindakan 1 & Tindakan \\
\cline { 2 - 4 } & Siklus 1 & Siklus 2 & Siklus 3 \\
\hline $\begin{array}{l}\text { Jumlah skor } \\
\text { Skor Maksimum }\end{array}$ & 1120 & 1961 & 2264 \\
$\begin{array}{l}\text { Individu } \\
\text { Skor Maksimum Kelas }\end{array}$ & 100 & 100 & 100 \\
$\begin{array}{l}\text { Jumlah siswa yang } \\
\text { tuntas }\end{array}$ & 3000 & 3000 & 3000 \\
$\begin{array}{l}\text { Jumlah siswa yg belum } \\
\text { tuntas }\end{array}$ & 21 & 20 & 29 \\
$\begin{array}{l}\text { Nilai rata-rata } \\
\text { Ketuntasan klasikal }\end{array}$ & 37,33 & 65,37 & 75,47 \\
\hline & $30 \%$ & $66,67 \%$ & $96,67 \%$ \\
\hline
\end{tabular}

\section{Analisis Data Deskriptif Kuantitatif}

1. Pencapaian Prestasi belajar siswa kelas XI ADM.A sebelum diberi tindakan

$$
=\frac{1120}{3000} \times 100=37,33
$$

2. Pencapaian prestasi siswa kelas XI ADM.A setelah diberi tindakan pengelompokan siswa berdasarkan nomor panggilan (acak berdasarkan tempat duduk )

$$
=\frac{1961}{3000} \times 100=65,37
$$

3. Pencapaian prestasi siswa kelas XI ADM.A setelah diberi tindakan pengelompokan siswa berdasarkan kemampuan akademik

$$
\begin{aligned}
& =\frac{2264}{3000} \times 100=75,47 \\
& \text { Dari hasil analisis tersebut dapat }
\end{aligned}
$$

disimpulkan bahwa

1. Terjadi peningkatan prestasi setelah diberi tindakan yaitu 37,33 menjadi 65,37 ada kenaikan sebesar $=28,04$

2. Dari sebelum tindakan ( siklus 1 ) dan setelah tindakan sampai dengan ( siklus 3 ) 34 menjadi 65,37 , dan dari( siklus 2 ) ke ( siklus 3 ) juga ada peningkatan sebanyak 75,47 - 65,37= 10,01 .

3. Rata - rata siswa sebelum diberi tindakandari $37,33 \%$ menjadi $\quad 96,67 \%$.

4. Dari tindakan siklus 2 dan setelah tindakan( siklus 3 ) 65,37 menjadi 75,47 berarti ada peningkatan prestasi sebanyak $75,47-65,37=0,01$.

Berdasarkan hasil penelitian di atas, maka hasil belajar siswa dengan menerapkan model pembelajaran Problem Possing hasilnya sangat baik. Hal itu tampak pada pertemuan dari 30 orang siswa yang hadir pada saat penelitian ini dilakukan nilai rata rata mencapai ; 37,33 meningkat menjadi 65,37 dan pada siklus 3 meningkat menjadi 75,47 .

Dari analisis data di atas bahwa penerapan model pembelajaran Problem Possing menunjukkan kegiatan belajar mengajar lebih berhasil dan dapat meningkatkan motivasi belajar siswa khususnya pada siswa kelas XI ADM.A di SMK Negeri 1 Narmada, oleh karena itu diharapkan kepada para guru dapat melaksanakan model pembelajaran Problem Possing .

Berdasarkan Kurikulum Tingkat Satuan Pendidikan ( KTSP ) siswa dikatakan tuntas apabila siswa telah mencapai nilai standar ideal 75 mencapai $\geq 85 \%$. Sedangkan pada penilitian ini, pencapai nilai $\geq 75$ pada ( siklus 3 ) mencapai melebihi target yang ditetapkan dalam KTSP yaitu mencapai 96,67\%. Dengan demikian maka hipotesis yang diajukan dapat diterima.

\section{SIMPULAN DAN SARAN}

Dari hasil kegiatan pembelajaran yang telah dilakukan selama tiga siklus, dan 
berdasarkan seluruh pembahasan serta analisis yang telah dilakukan dapat disimpulkan sebagai berikut: 1) Pembelajaran dengan menerapkanmodel pembelajaran Problem Possing mempunyai dampak positif dalam meningkatkan prestasi belajar IPA Fisika siswa kelas XI ADM.A di SMK Negeri 1 Narmada yang ditandai dengan peningkatan prestasi belajar siswa dalam setiap siklus, yaitu siklus I ( 37,33 ), siklus II( 65,37 ), dan siklus III $(75,47)$; 2) Penerapan model pembelajaran Problem Possing dengan latar pembelajaran kooperatif mempunyai pengaruh positif, yaitu dapat meningkatkan motivasi belajar siswa; 3) Penerapan model pembelajaran Problem Possing dengan latar pembelajaran kooperatif efektif untuk meningkatkan kembali materi ajar yang telah diterima siswa selama ini, sehingga mereka merasa siap untuk menghadapi pelajaran berikutnya.

Dari hasil penelitian yang diperoleh dari uraian sebelumnya agar proses belajar mengajar lebih efektif dan lebih memberikan hasil yang optimal bagi siswa, maka disampaikan saran sebagai berikut: 1) Untuk melaksanakan pembelajaran memerlukan persiapan yang cukup matang, sehingga guru harus mampu menentukan atau memilih topik yang benar-benar bisa diterapkan denganmodel pembelajaran Problem Possing dengan latar pembelajaran kooperatifagar diperoleh hasil yang optimal; 2) Dalam rangka meningkatkan prestasi belajar siswa, guru hendaknya lebih sering melatih siswa dengan kegiatan penemuan, walau dalam taraf yang sederhana, di mana siswa nantinya dapat menemukan pengetahuan baru, memperoleh konsep dan keterampilan, sehingga siswa berhasil atau mampu memecahkan masalahmasalah yang dihadapinya; dan 3) Perlu adanya penelitian yang lebih lanjut, karena hasil penelitian ini hanya dilakukan di SMK Negeri 1 Narmada tahun pelajaran 2017-2018 .

\section{UCAPAN TERIMAKASIH}

Terima kasih penulis sampaikan kepada Kepala Sekolah SMKN 1 Narmada yang telah mendukung kegiatan penelitian ini sehingga bisa selesai tepat pada waktunya.

\section{DAFTAR RUJUKAN}

Adinawan, M. Cholik. (2002). IPA Fisika Untuk SMA Kelas XI Semester I Jakarta : Erlangga.

Amerlin. (1999). Analisis Problem Possing Siswa Sekolah Dasar Negeri IIKecamatan Tomohon Kabupaten Minahasa Pada Konsep OperasiHitung Bilangan Cacah. Malang : IKIP Malang.
Andayani, Restu. (2001). Tugas Pengajuan Soal (Problem Possing) sebagai Pendekatan Dalam Proses Pembelajaran IPA Fisika di SMA. Makalah Komprehensif. PPs Unesa Surabaya.

Arends, Richard I. (1997). Classroom Instruction and Management. New York : MeGraw-Hill Companies, Inc.

Arikunto, Suharsimi. (1990). Manajemen Pengajaran Secara Manusiawi. Jakarta : Rineka Cipta.

$$
\text { (2007). Penelitian }
$$
Tindakan Kelas. Jakarta: PT Bumi Aksara.

Budhi, Wono Setya. (2004). IPA Fisika SMA Jilid $1 A$ Kelas $X$ Semester 1 Berdasarkan Kurikulum 2004. Jakarta : Erlangga.

Cramer, Kathleen, Post.T. \& Currier S. (1992). "Learning and Teaching Ratio and Proportion : Research Implication ". Douglas T. Owens ( ED ). Research Ideas For The Classroom : Middle Grades Matematics. 159-178 New York : Macmillan Publishing Company.

Dahar, R.W. (1993). Teori-Teori Belajar. Jakarta: P2LPTK Depdikbud, Dirjendikti.

Departemen Pendidikan Nasional. (2003). Kurikulum 2004 Standar Kompetensi Mata Pelajaran IPA Fisika SMA \& MA. Jakarta: Pusat Kurikulum Balitbang Depdiknas.

Depdiknas. (2004). Kurikulum 2004. Jakarta: Depdiknas

Efendi, En. (2000). Analisis Deskriptif Respon Siswa Terhadap Pembelajaran IPA Fisika yang Disertai Pemberian Tugas Pengajuan Soal. Makalah Komprehensif. PPs Unesa Surabaya.

Efendi, EN. (2001). Pemberian Tugas Pengajuan Soal Bedasarkan Masalah Pada Pembelajaran IPA Fisika Siswa Kelas II SLTP Muhamadiyah 5 Surabaya. Tesis. PPs Unesa Surabaya.

Hamzah. (2002). Pengembangan Model Pembelajaran IPA Fisika di SLTP Melalui Pendekatan Matematical Problem Possing“. Majalah IImiah Himpunan IPA Fisika Indonesia ( MIHMI ). Vol. 8 No. 3 Th. 2002. 29-38.

Hudojo, H. (1988). Mengajar Belajar IPA Fisika. Jakarta : Dirjen Dikti P2LPTK Depdikbud.

Johnson, David W, \& Johnson, Roger T. (2002). Learning Together and Alone : Cooperative, Competitive, and 
Individualistic Learning. Boston : Allyin and Bacon.

Johnson, David W, \& Johnson, Roger T. (2002). Meaningful Assessment AManageable and Cooperative Process. Boston: Allyn and Bacon.

Kanginan, Marthen. (2003). IPA Fisika (Untuk SMU Kelas I Semester I). Bandung : Grafindo.

Marpaung, Y. (1992). Profil Kemampuan Siswa SMA di Yogyakarta Menyelesaikan soal-soal Perbandingan Senilai dan Berbalik Nilai. Laporan Penelitian Yogyakarta: FMIPA IKIP Sanata Dharma.

Moses, B, Bjork, E. \& Goldenberg, E. P. (1993). "Beyond Problem Solving : Problem Possing ". Stephen I. Brown and Marion I. Oregan ( ED ). Problem Possing : Reflections and Applications. 178-188. New Jersey : Lawrence Erlbaum Associates, Publishers.

Mujib, A. I. (2003). Aplikasi Pembelajaran Kooperatif dengan Pendekatan Struktural di SMU. Makalah Komprehensif. PPs Unesa Surabaya.

Sabarata. (2003). Pengembangan Perangkat Pembelajaran Langsung Dengan Pendekatan Problem Possing Topik Relasi, Pemetaan Dan Grafiknya Di SLTP Negeri 2 Moyudan. Makalah Komprehensif. PPs Unesa Surabaya.

Silver, E. A, Mamona-Down. J, Leung S \& Kenney, P. A. (1996). "Possing Mathematical Problem". Journal for Research in Mathematics Aducation. Vol. 27 No. 3, Mei 1996. 293-309.

Silver, E. Dan Cai, J. (1996). " An Analisyis Of Arithmetic Problem Possing by Middle School Students ". Journal for Research in Mathematics Aducation 5, November 1996. 521-539.

Siswono, T. Y. E. (1999). Analisis Hasil Tugas Pengajuan Soal Oleh Siswa Madrasah Tsanawiyah Negeri Rungkut Surabaya. Makalah Komprehensif. PPs Unesa Surabaya.

Siswono, T. Y. E. (1999). Metode Pemberian Tugas Pengajuan Soal ( Problem Possing ) dalam Pembelajaran IPA Fisika Pokok Bahasan Perbandingan di MTs Negeri Rangkut Surabaya. Tesis. PPs Unesa Surabaya.

Slavin, Robert E. (1995). Cooperatve Learning : Theori, Research, and Practice 2nd Edition. Massachusetts : Allyn and Bacon.
Slavin, Robert E. (1997). Educational Psychology : Theori and Practise 5Th Edition. Boston : Allyn and Bacon.

Soedjadi. (2000). Kiat Pendidikan IPA Fisika di Indonesia : Konstatasi Keadaan Masa Kini Menuju Harapan Masa Depan. Jakarta : Dirjen Dikti Depdiknas.

Suhrta, I Gusti Putu. (2000). " Pengembangan Srategi Program Possing dalam Pembelajaran Kalkulus Untuk Memperbaiki Kesalahan Konsepsi ". IPA Fisika: Jurnal IPA Fisika atau Pembelajarannya. Th. VI No. 2, Agustus 2000. Malang : Jurusan Pendidikan IPA Fisika FPMIPA Universitas Negeri Malang.

Upu, Hamzah. (2003). Problem Possing Dan Problem Solving Dalam PembelajaranIPA Fisika. Bandung: Pustaka Ramadhan.

Wirodikromo, Sartono. (2002). IPA Fisika Untuk Kelas XI SMA. Jakarta : Erlangga. 